\title{
Exploração e precariedade na nova dinâmica produtiva nos canaviais e a persistência do desgaste e adoecimento do trabalho
}

\author{
Dathiê de Mello Franco-Benatti ${ }^{\mathrm{I}, 1}$, Vera Lucia Navarro ${ }^{\mathrm{II}}, 2$ e Luci Praun ${ }^{\mathrm{III},} 3$ \\ ${ }^{\text {I }}$ Prefeitura Municipal de Araraquara (Araraquara, SP, Brasil) \\ II Universidade de São Paulo (Ribeirão Preto, SP, Brasil) \\ III Universidade Federal do Acre (Rio Branco, AC, Brasil)
}

\begin{abstract}
Nas últimas décadas, o processo de trabalho no setor agrícola brasileiro passou por transformações. Essas alterações, desencadeadas em grande medida pela inserção de tecnologia e mecanização de etapas do processo produtivo, impuseram uma nova dinâmica ao trabalho nos canaviais, articulando antigas formas de organização e condições de trabalho com os imperativos da mecanização. Neste contexto, situações de suscetibilidade à ocorrência de acidentes e diferentes agravos à saúde, presentes no cotidiano do trabalho nos canaviais, renovaram-se. Exposição aos agrotóxicos, novas práticas de queima da cana, manuseio de máquinas e instrumentos de trabalho em um contexto de aumento da produtividade e intensificação do trabalho exemplificam esta situação. Este artigo tem por objetivo apresentar e problematizar situações de trabalho, assim como as circunstâncias de ocorrências de acidentes típicos e doenças com nexo laboral no segmento da agroindústria canavieira da região de Araraquara (SP). As reflexões desenvolvidas têm como ponto de apoio pesquisa de campo desenvolvida entre 2013 e 2014. A partir das entrevistas com 14 trabalhadores(as) pode-se compreender as distintas articulações entre as histórias de vida desses homens e mulheres e o cotidiano do trabalho nos canaviais. Os dados obtidos indicam que o ritmo e a jornada intensa de trabalho, em conjunto com a falta de equipamento de proteção, a exposição aos agrotóxicos e com outros riscos presentes no meio rural estão na base da ocorrência dos acidentes, marcas da ampliação da exploração e da precariedade do trabalho com o avanço de medidas de perfil neoliberal.
\end{abstract}

Palavras-chave: Trabalhadores(as) rurais, Canavieiros(as), Agroindústria canavieira, Saúde do(a) Trabalhador(a), Acidentes de trabalho.

Exploitation and precariousness in new productive dynamics in the sugar cane fields and the persistence of wear and illness at work

In the last few decades, the labor process in the Brazilian agricultural sector underwent important transformations. These changes, triggered to a great extent by the insertion of technology and mechanization of stages of the productive process, imposed new dynamics to labor in sugarcane fields, articulating old forms of organization and working conditions with the imperatives of mechanization. In this context, situations of susceptibility to the occurrence of accidents and different health problems that are quite present in the daily life of labor in sugarcane have been renewed. Exposure to pesticides, new practices of sugarcane burning, as well as the handling of machines and working tools in a context of increased productivity and intensification of work exemplify this situation. This article analyzes such labor conditions and situations, as well as the circumstances of occurrences of typical accidents and diseases resulting from labor relations in the sugarcane agribusiness segment of the Araraquara (SP) region. The considerations developed here are supported by field research developed between 2013 and 2014. Fourteen workers were interviewed, which allowed to understand the different articulations between the life stories of these men and women and the daily work in the cane fields. The data obtained indicate that the pace and intense working hours associated to lack of protective equipment, exposure to pesticides and other risks present in rural areas are the basis for the occurrence of accidents, marks of the expansion of exploration and precariousness with the advancement of neoliberal measures.

Keywords: Rural workers, Sugarcane cutter, Sugarcane industry, Worker's health, Accidents at work.

\footnotetext{
https://orcid.org/0000-0003-1180-1025

https://orcid.org/0000-0003-4669-0011

https://orcid.org/0000-0002-4386-324X
} 


\section{Introdução}

T a década de 1970, o Brasil foi considerado campeão mundial em acidentes de trabalho e, na atualidade, ocupa o quarto lugar no mesmo ranking. De acordo com o Ministério Público do Trabalho (2018) "a cada 48 segundos acontece um acidente de trabalho e a cada $3 \mathrm{~h} 38$ um trabalhador perde a vida" no país. Tais dados foram extraídos do Anuário Estatístico de Acidentes do Trabalho (AEAT). Segundo a publicação, foram registrados 712.302 de acidentes de trabalho (típicos, de trajeto e doenças) no Brasil em 2014 e nos anos de 2015 e 2016, 622.379 e 579.935 ocorrências respectivamente. Quando o foco se volta para as doenças do trabalho, os dados apontam que em 2014 foram contabilizadas 17.599 notificações e, de forma semelhante ao que aconteceu com o número de acidentes típicos, observou-se em 2015 e 2016 uma diminuição no número de registros: 15.386 e 12.502, respectivamente (Ministério da Fazenda, 2016).

Tais cifras, alarmantes, estão longe de refletir a realidade das ocorrências, recorrentemente marcadas pela subnotificação. Cabral, Soler e Lopes (2014) afirmaram que são vários os fatores contribuintes para a subnotificação dos acidentes de trabalho e que tais fatores estão relacionados ao tipo de ocorrência, à metodologia de investigação do acidente e à sua homologação pelo Instituto Nacional do Seguro Social (INSS). Entre outros fatores, a simples burla ao sistema de registro, fruto das consequências legais que envolvem os acidentes, deve ser considerada. Além deste motivo, as limitações relativas às fontes dos dados, circunscritas às Comunicações de Acidentes do Trabalho (CAT) e aos benefícios de natureza acidentária concedidos pelo INSS, também impõem restrições às estatísticas oficiais.

Considerando-se que a utilização da base de dados dos benefícios acidentários possa ampliar a captação de registros de acidentes de trabalho, duas outras ponderações precisam ser feitas. A primeira diz respeito ao fato de que os resultados obtidos traduzirem, fundamentalmente, ocorrências relativas aos trabalhadores com vínculo formal de emprego. Em um país com altas taxas de desocupação ${ }^{4}$ e informalidade ${ }^{5}$, onde as relações de trabalho encontram-se perpassadas pela precarização e flexibilização tanto contratual quanto salarial, ainda que se considere a importância dos dados colhidos e consolidados pelo poder público, a distância entre os indicadores oficiais e a realidade do cotidiano do mundo do trabalho é evidente. A curva descendente no registro de acidentes de trabalho, conforme indicam as estatísticas divulgadas pelo AEAT em 2016, deve ser considerada no contexto de uma taxa de desocupação em ascensão desde 2015, que salta nos anos subsequentes para dois dígitos e, nesse sentido, repercute nos registros oficiais.

A segunda ponderação se refere à instituição, pelo INSS, do Programa de Revisão dos Benefícios por Incapacidade (PRBI) em 2016. Com foco na revisão dos auxílios-doença e nas aposentadorias por invalidez, a iniciativa alcançou, em sua primeira etapa, "530 mil beneficiários com auxílio-doença e 1,1 milhão de aposentados por invalidez" (Ministério do Desenvolvimento Social, 2016). A segunda etapa do programa, iniciada em 2018, objetivou a análise de "1,2 milhão de benefícios por incapacidade, sendo 273.803 de auxílio-doença e 995.107 de aposentadorias por invalidez" (Instituto Nacional do Seguro Social, 2018).

De acordo com a médica Maria Maeno, em entrevista cedida ao Sindicato dos Bancários e Financiários de São Paulo, Osasco e Região (Motta, 2017), o problema não está em realizar

4 A taxa de desocupação, que no segundo trimestre de 2018 estava em 12,4\%, deve ainda ser observada em paralelo ao que o Instituto Brasileiro de Geografia e Estatística (IBGE) categoriza como taxa de subutilização da força de trabalho, indicador obtido a partir da articulação entre três componentes: "subocupados por insuficiência de horas trabalhadas"; "desocupados" e aqueles, com 14 anos ou mais, considerados como "força de trabalho potencial". Estas taxas, se considerado sempre o segundo trimestre de cada ano, também têm operado em curva ascendente. Os 14\% apurados em 2014, converteram-se em 17,2\% em 2015; 20,9\%, em 2016; 23,8\%, em 2017; 24,6\% em 2018, conforme o IBGE (2018).

5 Compõem o mercado de trabalho informal: trabalhadores(as), do serviço público ou privado, sem registro, que trabalham por conta própria, mas sem CNPJ, assim como o segmento de trabalhadores(as) domésticos sem carteira de trabalho registrada. O IBGE considera também como parte desse contingente aqueles(as) que trabalham em família. 
a revisão, pois uma trabalhadora ou trabalhador que é aposentado por invalidez e que apresenta uma melhora de sua funcionalidade pode ser reinserido no trabalho, desde que respeitado um processo de reabilitação profissional específico para cada caso. $O$ problema está na forma como essa revisão ocorre, com o objetivo único de cessar o maior número possível de benefícios "para que se diminua os gastos do INSS. Por isso, paga-se R \$ 60,00 por fora do salário do perito para que ele participe do mutirão da revisão de benefícios. A avaliação é feita sob quais critérios? Ninguém sabe" (Motta, 2017).

Dal Rosso, Barbosa e Fernandes Filho (2001, p. 88) afirmam que, devido aos acidentes de trabalho, "Vidas de trabalhadores são sacrificadas, seus corpos e suas mentes, mutilados; carregam durante intervalos ou para o resto de sua vida, as marcas desse tipo de violência". Praun (2016) descreveu o sentimento de inutilidade vivenciado por aqueles que, adoecidos e/ou mutilados, são impedidos de se manter no mercado de trabalho, descartados sem direito a auxílio acidentário, estabilidade e demais benefícios que lhes são devidos. Cohn, Hirano, Karsch e Sato (1985, p. 11) consideraram o acidente de trabalho como uma das mais brutais formas de violência urbana dado que tal violência "não se limita ao momento do acidente e à lesão física, na esmagadora maioria dos casos irreversível, mas .... é apenas o início de uma longa trajetória marcada fundamentalmente pelo desrespeito aos direitos mínimos de cidadania".

Em consonância com as perspectivas acima destacadas, as análises propostas por este artigo inserem-se entre aquelas que consideram os processos de reorganização do trabalho, assim como seus desdobramentos deletérios entre os trabalhadores e trabalhadoras, como parte de um movimento de maior amplitude, característico da atual fase de desenvolvimento do capitalismo e articulado pelo avanço das medidas de perfil neoliberal. Esse movimento, observado globalmente, assume formas singulares nos países que compõem a chamada periferia do sistema, evidenciando nestes espaços exploração e precariedade ampliadas.

O setor agrícola brasileiro, fortemente reestruturado nas últimas décadas, é locus de velhas e novas formas de organização do trabalho, tecidas tanto pelo papel reservado ao Brasil na divisão internacional do trabalho como em meio ao avanço significativo, impulsionado pelas corporações do agronegócio, do uso de tecnologia de ponta. O reconhecimento dessa articulação singular, desenvolvida em um espaço historicamente marcado pela profunda exploração do trabalho, é premissa das análises expressas neste artigo, que têm como foco o setor canavieiro.

As condições e situações de trabalho cotidianas e suas expressões nos indicadores de acidentes e doenças do trabalho assumem neste universo, portanto, contornos particulares. Mesmo considerada a incidência de subnotificações, as atividades relacionadas ao cultivo da cana-de-açúcar figuram dentre aquelas com maior registro de acidentes e doenças do trabalho: em 2015 foram registrados 2.112 acidentes de trabalho naquela atividade e, em 2016, 1.984 (Ministério da Fazenda, 2016).

Pesquisa recente, desenvolvida por Verçoza (2018) e que contou com a participação de 22 canavieiros safristas em atividade em usinas localizadas no município de Teotônio Vilela, Alagoas, tornou contundente o nexo entre processos de adoecimento, óbito, e atividade laboral desenvolvida no corte da cana. Valendo-se do uso de monitores de frequência cardíaca, foi possível registrar os batimentos cardíacos destes trabalhadores ao longo da jornada de trabalho. Entre os achados da pesquisa, vale destacar um dos participantes, que já na primeira hora de uma jornada que se estendeu por 10 horas, alcançou 200 batimentos por minuto (bpm).

Este artigo, que se embasa em resultados de pesquisas realizadas entre 2013 e 2014, tem por objetivo apresentar as circunstâncias de ocorrências de acidentes de trabalho no âmbito da agroindústria canavieira da região de Araraquara, no estado de São Paulo, Brasil, e suas consequências para os trabalhadores e trabalhadoras do setor a partir da análise do processo de trabalho.

Para o desenvolvimento da pesquisa, de caráter qualitativo, foram realizadas entrevistas semiestruturadas com 14 participantes com idades que variaram entre os 22 e os 55 anos, 
dentre os quais nove mulheres e cinco homens vitimados por algum tipo de acidente durante o trabalho na lavoura canavieira. Os entrevistados e entrevistadas executavam suas atividades em diferentes usinas da região, o que possibilitou maior abrangência da observação e análise das condições e situações de trabalho tratadas pelo estudo.

Os critérios de inclusão dos entrevistados e entrevistadas foram os seguintes: trabalhadores e trabalhadoras da agroindústria canavieira envolvidos com a colheita da cana-de-açúcar que sofreram acidentes de trabalho entre 2010 e 2012 e que concordaram em participar do estudo mediante assinatura do Termo de Consentimento Livre e Esclarecido.

Também foi realizada uma entrevista com a gestora do Centro de Referência em Saúde do Trabalhador (Cerest) de Araraquara, SP, a fim de obter informações acerca do atendimento dispensado aos acidentados. Tal órgão teve fundamental importância no fornecimento de dados que possibilitaram o contato das pesquisadoras com os trabalhadores e trabalhadoras entrevistados.

As entrevistas foram agendadas previamente e realizadas nos domicílios dos participantes. Com autorização prévia, as entrevistas foram gravadas e, posteriormente, transcritas integralmente. De forma a preservar o anonimato dos e das entrevistadas, procedeu-se à identificação por nomes fictícios, atribuídos pelas pesquisadoras.

Quando da realização das entrevistas, dos 14 trabalhadores e trabalhadoras que participaram da pesquisa, dez $(71,4 \%)$ relataram haver cursado apenas o ensino fundamental e, dentre esses, apenas três o completaram e, do total, apenas quatro trabalhadores $(28,6 \%)$ haviam completado o ensino médio, um deles através de curso supletivo.

Transcritas as entrevistas, foi realizada uma leitura sistematizada dos depoimentos e os dados obtidos foram categorizados como: aspectos da organização e das condições do trabalho rural; processo de trabalho; riscos aos quais esses trabalhadores estão expostos ao exercerem suas atividades; queixas a respeito da saúde física e mental e tipificação dos acidentes de trabalho que ocorrem no meio rural.

O artigo apresenta os resultados da pesquisa de campo em diálogo com a produção bibliográfica pertinente ao tema. Além desta introdução, está organizado em outras seis seções que buscam apresentar e discutir os diferentes aspectos que envolvem a dinâmica produtiva nos canaviais e sua articulação com a persistência do desgaste e adoecimento do trabalho entre canavieiros.

Nestas seções, busca-se relacionar a saúde dos e das trabalhadoras com os aspectos da organização e condições de trabalho. Destaca-se a questão da inovação tecnológica no meio rural, intensificada nas últimas décadas, que reorganizou a atividade na lavoura canavieira; a vinda dos trabalhadores rurais oriundos de outras regiões do país para o trabalho no canavial no interior paulista; a produtividade na lavoura canavieira, destacando-se as metas de produção que o trabalhador rural precisa atingir e, assim, relaciona-se a produção com a forma de remuneração; as condições de trabalho que os trabalhadores rurais estão expostos como os riscos físicos, químicos e psicológicos, que podem contribuir para as ocorrências de acidentes e adoecimentos; e as consequências dos acidentes de trabalho no meio rural, muitas vezes graves, que deixam sequelas e podem incapacitar para a volta ao trabalho, além de repercutirem de várias formas em sua vida como um todo.

\section{Atividade agrícola, inovação tecnológica e reorganização do trabalho}

Em decorrência de processos de inovação tecnológica intensificados nas últimas décadas, o trabalho no meio rural brasileiro passou por profundas transformações que afetaram as condições e situações de sua execução, deixando os e as trabalhadoras mais suscetíveis à ocorrência de formas diferenciadas de acidentes e a diferentes agravos à saúde. A exposição a agrotóxicos, 
as novas práticas de queima da cana e o manuseio de máquinas e instrumentos de trabalho em um contexto de intensificação do trabalho exemplificam esta situação.

Na década de 1960, o Brasil implantou um rigoroso processo de reestruturação das usinas de cana-de-açúcar. Vinte anos após, a produção de cana aumentou em decorrência da incorporação de novas técnicas de cultivo e da mecanização da lavoura. Segundo dados da União da Indústria de Cana-de-Açúcar (Unica), a produção de cana-de-açúcar no Brasil, em 1980, elevou-se para 123,681 milhões de toneladas. Nos anos seguintes, em 1981 e 1982, o número da produção caiu para 91,081 e 101,981 milhões de toneladas, respectivamente. Mas a queda foi revertida nos anos de 1983 e 1984, atingindo a marca, entre os anos de 1985 e 1986, de 223,179 milhões de toneladas de cana-de-açúcar (Unica, 2019).

Em parte, as repercussões desse processo de inserção tecnológica e reorganização do trabalho, que elevaram qualitativamente a produtividade na agricultura, puderam ser observadas na saúde dos e das trabalhadoras. Para Veiga, Gontijo, Masiero, Maas e Odorizzi (2017, p. 125), "o crescimento da frota de tratores agrícolas incrementou o número e a gravidade dos acidentes no campo". Essas alterações envolvem por um lado as inovações no campo da biotecnologia, implicando, entre outros procedimentos, na adoção de insumos, tais como sementes, fertilizantes, defensivos; por outro, novas práticas de cultivo e inovações mecânicas, com o aumento gradativo do uso de máquinas e implementos agrícolas (Araújo, Schuch, Barros, Shirota \& Nicolella, 2003).

Penteado, Sanches, Castelane, Valderrama e Magagnini (2013) afirmaram que o cortador de cana na atualidade convive na lavoura tanto com tecnologias de ponta quanto com condições tradicionais de plantio e corte. O número de acidentes do trabalho na cultura da cana-deaçúcar é muito elevado em função de fatores que envolvem as queimadas de cana, a postura física exigida para o trabalho braçal no corte e a utilização das ferramentas manuais de trabalho, como facões e podões.

Deve-se destacar que o trabalho no corte da cana é remunerado de acordo com a quantidade cortada pelo trabalhador. Alves $(2008$, p. 8) relatou que, no início dos anos 2000, "para um cortador manter-se empregado no corte de cana [era] necessário que ele [cortasse] um mínimo, que [variava] entre 9 e 10 toneladas de cana/homem/dia”. Em pesquisas realizadas, em 2015, com trabalhadores rurais da lavoura da cana-de-açúcar no interior de Minas Gerais, Matos, Fratari e Carvalho (2018) constataram que os cortadores chegaram a cortar 12 toneladas de cana queimada por dia, contra 6 toneladas de cana não queimada.

A queima da cana antes de seu corte tem por finalidade permitir que o trabalhador corte mais cana em um menor período. Dessa forma, os movimentos repetitivos, em virtude do ritmo acelerado para cortar uma maior quantidade de cana, deixam os trabalhadores mais suscetíveis aos acidentes e adoecimentos.

As máquinas colhedoras de cana têm destaque nestas ocorrências em virtude do potencial de gerarem acidentes de maior gravidade, muitas vezes fatais, ou que deixem sequelas em suas vítimas que as acompanham pelo resto da vida, como amputações e mutilações (Rodrigues, 2014).

\section{Travessias em busca de trabalho}

De acordo com Alves (2007), nos anos de 1980, os trabalhadores e trabalhadoras que vinham para safra da cana no Sudeste provinham principalmente da Bahia, do norte do Paraná e do Vale do Jequitinhonha em Minas Gerais. A partir dos anos de 1990, em virtude da expansão da área plantada da cana-de-açúcar, ocorreu uma expansão do mercado de trabalho na cultura da cana, dando-lhe uma configuração nacional. Com isso, começou a chegar às lavouras do Sudeste grande 
número de trabalhadores e trabalhadoras oriundos da Paraíba, Piauí e Maranhão, como relata um dos entrevistados:

[Vim de] Riachão de Jacuíbe, na Bahia, perto de Feira de Santana. Isso aqui é como um destino, né? No Nordeste é mais difícil do que aqui, às vezes você não cresce na vida porque você não tinha oportunidade pra crescer. Aí, você tem aquele foco de seguir na frente, pra ganhar a vida. Você tem a parte solitária, porque você deixou sua família, deixou parte de sua felicidade por lá. Assim, tem que enfrentar tudo que vem pela frente, você enfrenta muito o preconceito (José, 35 anos).

A migração para o Sudeste é uma realidade das pessoas que habitam as regiões mais pobres do país, como o interior do Maranhão, do Piauí e outras regiões do nordeste brasileiro. Muitos destas e destes trabalhadores se inseriram no trabalho ainda crianças na região onde nasceram ou quando migraram para o estado de São Paulo. Eles buscam com a migração melhores condições de vida e de trabalho. De acordo com Nunes, Silva e Cordeiro (2016), um dos fatores que contribuem para a migração em busca de trabalho e remuneração é a dificuldade de acesso à terra, aliada às irregularidades das chuvas e à ausência de emprego nos municípios de origem. $\mathrm{O}$ trabalho, desde muito cedo, marca a vida desses homens e mulheres:

Comecei a trabalhar com seis anos de idade. Eu plantava, colhia, mexia com enxada, com machado, com serrote, com carpideira. Com sete anos eu fui pra escola, com sete anos eu chegava, almoçava e minha enxada estava no batente da porta me esperando pra eu ir pra roça. Ali eu carpia de enxada, eu plantava com aquelas maquininhas teco-teco. No tempo de colheita, amanhecia na roça, batendo feijão, arrancava feijão o dia inteiro. Então, eu já fiz de tudo, já trabalhei de dia, de noite, já apanhei porque não aguentava trabalhar (Mariana, 52 anos).

Meu pai tinha uma "chacrinha", mas eu sempre trabalhei na roça, desde menina. Na verdade, eu tinha acho que uns oito anos. Com nove anos, eu morei dois anos com a minha irmã mais velha porque ela casou, eu ajudava meu cunhado no retiro, tirar leite. Depois voltei pra casa, e a gente sempre trabalhou na roça, plantava arroz, milho, feijão. Depois com 15 anos, 14 anos, daí eu já trabalhava fora, assim na fazenda, trabalhava na laranja, era safrista, carpia, serviços de colheita de cana (Ana, 59 anos).

Muitos trabalhadores e trabalhadoras iniciaram o exercício laboral ainda quando crianças na região de origem ou quando migraram para o estado de São Paulo com o objetivo de trabalhar na lavoura de cana-de-açúcar ou laranja. Essa é uma realidade social decorrente das condições de vida vivenciadas pelas famílias que habitam as regiões mais pobres do Brasil; a maioria dos trabalhadores que migram para o trabalho na lavoura açucareira vem para o corte de cana devido à falta de emprego na região de origem.

Rosa e Navarro (2014) observaram que a dificuldade de alguns trabalhadores e trabalhadoras em se manterem como pequenos produtores, assim como a falta de trabalho assalariado em seus locais de origem fazem com que migrem para a região Sudeste em busca de trabalho para garantir o sustento da família. O intermediador do processo de contratação é conhecido, entre os e as trabalhadoras, como "gato". A figura do "gato", que também é chamado de turmeiro, é quem seleciona candidatos para o trabalho na lavoura e organiza a viagem até a região do interior paulista.

Era empreiteiro, né? A usina contratava, eles falavam "gatos" e eles pegavam a gente. A usina não tinha nada a ver, tudo era eles ["os gatos"] que contratavam, que dispensavam. Eles vinham atrás. 
Se você trabalhasse bem, trabalhasse certinho, não era de perder dia, tudo isso conta. Na outra safra, eles vinham procurar outra vez. Então, eu mesmo trabalhei seis anos com um "gato" só. Todo ano ele tava no portão aqui de casa, me chamando (Cláudia, 44 anos).

De forma geral, os entrevistados relataram a precariedade das condições de moradia a que eram submetidos os trabalhadores e trabalhadoras migrantes. Nos alojamentos, dividiam quartos com mais de dez pessoas precisando, não raro, improvisar um lugar para dormir no chão. Outros preferiam alugar casas na periferia da cidade.

Os maranhenses mesmo moravam, alugavam uma casa de cinco cômodos, aí moravam dez, quinze numa casa só. Aí eles mesmos cozinhavam. Eles mesmos lavavam a roupa, sabe? As condições não eram boas não. Eles mesmos tinham que se virar, porque os turmeiros buscavam, mas só que na hora de levar, ficava por eles mesmos. Eles tinham que ir embora por eles. Por exemplo, acabava a safra, eles que se viravam pra ir embora, mas pra trabalhar o empreiteiro que ia buscar. Eles falavam que traziam eles de longe e não dava nada, não dava cama, só dava o alojamento. Aí tinha muitos que dormiam no chão, forravam ali com cobertor e ficavam a safra inteira ali no chão (Cláudia, 44 anos).

A precariedade das condições de moradia a que são submetidos esses homens e mulheres também foi relatada por Nunes et al. (2016), que encontraram trabalhadores morando em barracos e alojamentos nas periferias das cidades.

Segundo Rosa e Navarro (2014), as usinas têm preferência na contratação de migrantes por tratar-se de pessoas simples, pobres, habituadas a lidar com trabalhos pesados e a viverem em situações adversas. É certo que o baixo grau de escolarização implica em um menor poder de negociação, o que faz com que esses homens e mulheres aceitem submeter-se às formas precárias de contratação e aos baixos salários praticados no setor.

\section{"Quanto mais se corta, mais se ganha"}

O espaço de trabalho na lavoura de cana é o canavial, que é dividido em talhões. Cada talhão é composto por linhas de canas plantadas paralelamente e cercados por ruas mais largas, conhecidas como carreadores, onde circulam os tratores e caminhões que realizam o transporte da cana cortada para a usina (Ferreira, Gonzaga, Donatelli \& Bussacos, 2008).

O processo de trabalho na cultura da cana-de-açúcar tem diferentes etapas, como o preparo do solo, a escolha da variedade agrícola da cana, o plantio, a adubação, a conservação do solo, o corte, o carregamento e o transporte para as usinas.

A jornada de trabalho dos trabalhadores rurais começa muito cedo, ainda antes do amanhecer. De forma geral, eles se levantam por volta das $4 \mathrm{~h}$ da manhã para preparar a marmita, os equipamentos de trabalho e fazer o café. Por volta das 5 h20 dirigem-se ao ponto de ônibus, chegando na roça por volta das $7 \mathrm{~h}$. No final da tarde, por volta das $17 \mathrm{~h}$, a atividade na lavoura é encerrada.

Olha, nós saíamos de casa [às] 5h20. Nós começávamos o serviço [às] 7h00. É das 7h às 15 h40 de segunda a sábado. Eu levanto 4h, aí eu arrumo a marmita, me troco, às vezes, se dá tempo, eu ponho roupa pra bater, vou lavar a louça, aí depois que eu pego e saio. Às vezes eu tomo [café da manhã em casa], às vezes não. Aí toma na hora que está indo. Aí para o serviço [às] 15h40. Depende do lugar que a gente está, às vezes está perto, às vezes está longe. A gente chega aqui numa base de $16 \mathrm{~h} 30$ e 17h. Agora, quando é longe, é uma base de 18h (Vitória, 39 anos). 
Scopinho, Eid, Vian e Silva (1999), em estudo realizado nos anos 1990, alertaram que o avanço da mecanização do corte da cana-de-açúcar no estado de São Paulo provocava não só a extinção de postos de trabalho, mas repercutia também na saúde dos trabalhadores e das trabalhadoras, assim como impactava o meio ambiente.

$\mathrm{Na}$ atualidade, apesar de ser significativo o uso de máquinas para colheita da cana, as usinas continuam empregando homens e mulheres para o corte manual. A demanda para o corte manual permanece, uma vez que o processo de mecanização ainda não alcançou 100\% da área plantada (Nunes et al., 2016). Um dos entrevistados, ao relatar sobre o processo de inserção de tecnologia no cultivo e corte da cana-de-açúcar, destaca os diferentes níveis de mediação observados entre processo de trabalho manual e presença da tecnologia.

Tem a parte do solo, que eles preparam tudo a terra, vem com adubo, com enxofre, aí depois que prepara tudo vem o corte manual, o corte mecanizado é a mesma coisa que a colheita faz, só que é tudo na máquina. A mesma cana ela corta pra moer, ela corta. É tipo de processo diferente, é a mesma máquina, aí a máquina vem sulcando, aí já planta, já sulca, já cobre, e já joga veneno. E no manual é diferente. Eles vão, cortam a cana, a máquina vem pra colocar no caminhão, depois o caminhão desemboca até onde está plantando. O caminhão coloca num local perto, aí vem o manual no outro dia e vão jogando dentro do sulco (José, 35 anos).

O trabalho manual do canavieiro é essencialmente fundado na lógica de pagamento por peça, o que, por conta dos baixos salários, impõe uma alta intensidade e produtividade ao trabalho, ainda que não comparável ao processo mecanizado. Mesmo em situações nas quais o salário encontre-se pré-estabelecido, como no caso daqueles que trabalham por diárias, a produtividade alcançada pelos e pelas trabalhadoras incide na sua permanência ou não no corte da cana.

A presença do maquinário no processo produtivo, por sua vez, também pressiona pela ampliação da produtividade e intensidade do trabalho, já que também incide nos parâmetros finais de rendimento do plantio e da colheita. Quanto a aqueles e aquelas que operam colheitadeiras, ainda que recebam salários fixos, também possuem metas a serem cumpridas ao final de cada dia de trabalho.

O trabalho na lavoura envolve um profundo desgaste físico. Já no ônibus, durante o trajeto para o trabalho, é comum que os e as trabalhadoras tomem café e consumam um pouco da marmita: "Tomava no ônibus, antes de começar, café, pão", afirmou um dos entrevistados.

Você vai comendo, no ônibus, porque chega lá $7 \mathrm{~h}$, tem que pegar e trabalhar, porque tem vez que passa da hora, né? Eu comia um pouco da comida e depois no almoço eu comia o resto (Paula, 43 anos).

A intenção, ao se alimentar antes do início de sua jornada na lavoura, não é somente ganhar tempo para cortar maior quantidade da cana. Ao alimentar-se logo cedo, consegue tanto beneficiar-se da marmita ainda aquecida, como criar condições para suportar a perda da energia imposta pela dura jornada no corte ou na lavoura da cana-de-açúcar.

Tem que comer bastante, senão não aguenta não (Pedro, 42 anos).

Os trabalhadores e trabalhadoras do turno da noite, que operam as máquinas agrícolas, também têm pausas para uma refeição na jornada de trabalho. No horário de janta, eles não optam por comida, mas preferem consumir frutas, bolachas, chocolates e balas. Uma das entrevistadas argumenta que 
no momento, eles não estão disponibilizando [marmita], aí a gente leva de casa. Eu levo mais é fruta, bolacha integral, essas coisas (Carolina, 23 anos).

De acordo com Novaes (2007), a ingestão alimentar, somada às exigências do trabalho na lavoura, não repõe suficientemente as energias que o indivíduo perde durante os movimentos que executa para o corte na lavoura. Alessi e Navarro (1997) destacaram o baixo valor proteico da alimentação dos e das trabalhadoras rurais, assim como a grande perda de líquidos devido ao esforço físico dispendido durante a jornada de trabalho.

De acordo com Alves (2007), a partir da década de 1990 houve grande aumento da produtividade do trabalho. Antes era preciso que se cortasse no mínimo 10 toneladas de cana por dia para manter o emprego. Essa média expandiu-se para 12 toneladas.

Existe uma variedade nos tipos de cana-de-açúcar e isso repercute na quantidade cortada manualmente. Segundo os entrevistados, a cana em pé é a cana-de-açúcar cuja metragem cortada é superior aos outros tipos de cana; porém, o valor pago por ela é inferior. Assim, corta-se uma maior quantidade em função desse tipo de cana ser mais fácil de cortar, mas recebe-se um salário menor. Já a cana tipo pé de rolo é a cana mais difícil para se cortar. Para esta, o valor pago é maior, pois é uma cana-de-açúcar mais pesada.

Tem diferença, tem as canas em pé, tem cana mais fina, tem uma que chama rabo de burro, pequenininha, com uns feixinhos assim, isso não rendia de jeito nenhum. E a cana rolo, cana rolo é pesada pra caramba. Ela é boa, só que ela rendia mais no preço. A cana rolo é tudo tombada, é cana grossa que cai com o vento e que a gente chama de cana rolo. As outras são em pezinho, mas tem fina e tem grossa. O máximo que eu consegui cortar de cana foi 150 metros (Ana, 59 anos).

Ah, 200 e pouco [metros], depende da cana, né? Se fosse uma "raleirinha", de pezinho, você corta até 300 metros (Paula, 43 anos).

De acordo com Novaes (2007), as particularidades do corte manual, em um contexto de inserção de maquinário e de intensificação da produção, implicam em novas formas de controle do trabalho no corte da cana. Dentre essas formas, tem-se o ganho pela produtividade, pela metragem e pesagem da cana cortada. "Somando-se a esses critérios o tipo da cana cortada, tem-se a referência para calcular o salário. Assim, a lógica da eficiência do corte manual é determinada pelo lema: 'Quanto mais se corta, mais se ganha'" (Novaes, 2007, p. 171).

No corte mecanizado, os trabalhadores também sofrem o controle pela produção. Os operadores de máquinas colheitadeiras e que trabalham no turno da noite têm uma metragem de cana para cortar durante o turno, conforme a fala a seguir:

Por produção, a gente tinha que ter dois hectares por dia. Andar dois hectares. Aí, eles mediam a quantidade de ruas que você fizesse e aí dividia, né? (Carolina, 23 anos).

Os operadores e operadoras de colheitadeira, apesar de terem metas a serem atingidas, recebem salário fixo, que giravam em torno de $\mathrm{R} \$ 1.800,00$ a $\mathrm{R} \$ 1.900,00$ ao mês no ano de 2013. Os cortadores e cortadoras manuais recebem o salário por produção quando estão trabalhando no regime de empreita e salário fixo quando trabalham em regime de diária. A base salarial deles é em torno de $\mathrm{R} \$ 700,00$ a $\mathrm{R} \$ 800,00$ ao mês. Quando conseguem atingir uma boa meta de corte de cana-de-açúcar, o salário varia de $\mathrm{R} \$ 1.000,00$ a $\mathrm{R} \$ 1.200,00$ ou até um pouco mais. 
Os trabalhadores e trabalhadoras, em meio ao exercício de sua atividade, desenvolvem alguns macetes para facilitar a execução da atividade e, dessa forma, também obter um bom rendimento na produção. De acordo com Dejours (1992, p. 105), "aprendem, espontaneamente, ao longo do tempo e por hábito, uma série de dicas, que são a forma pragmática e operatória do saber do trabalhador".

Quando você entra no eito, você mesmo descobre o jeito de trabalhar (Ana, 59 anos).

Quem não sabe fica pra trás, mas todo serviço tem que ter uma manha (Mariana, 52 anos).

Essa "manha" ou engenhosidade, conforme Dejours (2012), contribui para o aumento da produtividade e da intensidade do trabalho realizado.

De acordo com Vilela, Laat, Luz, Silva e Takahashi (2015), os trabalhadores e as trabalhadoras rurais, migrantes que vêm de outras regiões do país, têm os contratos de trabalho formalizados após o período de experiência de três meses na atividade. Ao longo deste período ocorrem baixas na equipe, especialmente daqueles que participam pela primeira vez da atividade; a atividade no corte da cana é percebida pelos trabalhadores como pesada e exaustiva, o que resulta na desistência de alguns antes do término da safra.

\section{Trabalho duro, arriscado, sofrido e sem valor}

A remuneração por peça, assim como a instituição de metas de produção, incentiva a competição entre os trabalhadores no corte, fazendo com que uns se sintam motivados a igualar a quantidade de cana que outros cortaram. Tal dinâmica tende a acentuar o desgaste do corpo já próprios da atividade e das condições de sua realização. Essa competição é tratada por Vilela et al. (2015) como uma medida organizacional. Segundo os autores, para acelerar o trabalho e manter a produtividade, a chefia designa dois trabalhadores para cortar cana nas mesmas ruas e em direção oposta, estabelecendo uma disputa entre eles.

Em nossas pesquisas, os trabalhadores e as trabalhadoras relataram a existência de competição entre os trabalhadores no corte de cana. Os trabalhadores veem os outros colegas de trabalho cortando uma maior quantidade de cana-de-açúcar e, devido a isso, se sentem motivados para acompanhá-los no eito, tentando igualar a quantidade de cana que a outra trabalhadora ou trabalhador cortou. Este esforço físico acarreta um desgaste do corpo do indivíduo, em virtude ao ritmo intenso da atividade, somado às condições de trabalho, principalmente nos dias mais quentes do verão:

Tem trabalhador que fica perto ali cortando cana, mas o outro corta mais, ele quer acompanhar, mas ele não consegue, então ele vai puxando, puxando, puxando, dá aquele cansaço, ainda mais no sol quente, e quando o sol esquenta mesmo, tem gente que não aguenta, não tem condições de igualar o eito e fica pra trás. E os outros vão indo (Lúcia, 22 anos).

Muitos relatam sofrer perda de peso quando estão em época de safra, principalmente quando realizam a atividade na plantação e no corte de cana-de-açúcar. 
Mas você perde bem peso de notar na aparência da pessoa, que a pessoa emagrece e emagrece bem mesmo, porque é um trabalho desgastante, né? Esforçado, você sua muito, devido você se esforçar bastante, você vai suar bastante, e é onde você perde líquido, e peso. Cansaço sim, cansaço a gente sente (Vitor, 44 anos).

Devido à grande perda de sais minerais em virtude do esforço que exercem para cortar a cana, a usina fornece uma substância isotônica a ser tomada durante o dia de trabalho para repô-los durante a execução da atividade. Com essa substância, as dores do corpo e a câimbra diminuem e, consequentemente, a produtividade aumenta. "Não se pode, de fato, saber quais as intenções de quem os fornece, mas, é certo que seu uso faz com que se amplie a produção do cortador" (Rosa \& Navarro, 2014, p. 154). Os autores destacam que são comuns e frequentes as ocorrências de dores e de câimbras durante a execução da atividade na lavoura: "Sofrer com dores, cãibras, perder o apetite, vomitar são mazelas tão comuns que passaram a fazer parte da 'normalidade' do trabalho" (Rosa \& Navarro, 2014, p. 152).

De acordo com Silveira, Robazzi, Marziale e Dalri (2005), trabalhadores rurais executam suas atividades em ambiente favorável à ocorrência dos acidentes de trabalho. Trata-se de atividade perpassada por riscos físicos, pois o trabalho é realizado em locais sem abrigo; por riscos químicos, em decorrência da aplicação de variados produtos agrícolas, poeiras do próprio solo levantadas pelos ventos; por riscos ergonômicos, em função do peso que carregam; e por riscos biológicos, pela presença de animais que podem lhes causar ferimentos.

Muito triste viu? Muito horrível. Ficar tomando sol aí acaba com a pele, tem que ficar passando protetor. As pessoas têm até câimbra, fica ruim cortar cana com esse solzão. O trabalho do cortador é sofrido, e não tem valor, né? Se fosse ver, o povo da roça era para ganhar bem. É um trabalho muito sofrido, desgastante e não ganha quase nada (Paula, 43 anos).

Aqueles e aquelas que exercem atividades no corte mecanizado também enfrentam condições inadequadas ao manobrar as máquinas agrícolas:

As máquinas são até boas, não poderia dizer que é ruim, né? Mas tem muita coisa lá que deveria melhorar, pela nossa segurança, pelo fato de você subir escada. Na chuva é perigoso pra subir. E fora as condições de veneno que a gente trabalha com veneno, adubo e eu acho que essa parte é ruim (Carolina, 23 anos).

Scopinho et al. (1999) destacam que mesmo estando em cabines, estão em contato direto e indiretamente com animais peçonhentos, assim como no corte manual. Quando a cana não é queimada e as cabines não possuem sistema de ventilação, o e a trabalhadora ficam expostos ao contato, já que a total vedação das janelas das cabines é impedida.

Com relação às condições de trabalho no corte mecanizado, Rodrigues (2014) destaca que, se por um lado o corte mecanizado de cana proporciona uma diminuição dos riscos físicos (radiação solar, calor, frio, temperatura), dos riscos químicos (poeira e fuligem), e dos riscos mecânicos, por outro, não elimina riscos biológicos e químicos, acentuando as cargas laborais e suas repercussões psíquico-físicas e incorporando novos elementos de risco, a exemplo do ruído e das vibrações. É nesse contexto que Bezerra e Tavares (2016) destacam que o progresso científico que se verifica na agroindústria canavieira não implica necessariamente melhorias reais nas condições de trabalho dos cortadores de cana. 
A chuva é outro fator destacado pelos e pelas trabalhadoras como prejudicial à saúde e que oferecem risco de acidentes devido aos raios, aos tombos e às entorses por causa do solo úmido e escorregadio:

Olha eu cheguei a pegar época que se chegasse na lavoura e "tivesse" chovendo, não desceria da condução. Muitas vezes, você tava trabalhando vinha a chuva e você continuava. Parou a chuva e inventei de trabalhar, aí fica mais lisa e é onde eu acabei me acidentando. Teve vezes de a gente passar o dia inteiro dentro do ônibus (Vitor, 44 anos).

Como a maioria ganha por produção, a realização da pausa também tende a não ser respeitada, sendo por vezes vista como negativa para o trabalhador, pois implica na queda da produtividade e, consequentemente, da remuneração: “... por trás das folhagens, a exploração do trabalho continua. As pausas para as refeições (almoço e lanche) não são respeitadas; os trabalhadores são incentivados a atingirem e mesmo ultrapassarem as médias de produtividades vigentes" (Nunes et al., 2016, pp. 1129-1130).

Outro aspecto a ser destacado é o da queima da cana-de-açúcar. No Brasil, essa prática ainda é comumente usada na colheita manual antes do corte da cana. $O$ objetivo desse procedimento é facilitar as operações de colheita, pois evita a retirada da palha da cana.

Atualmente, discute-se o fim das queimadas. A Lei no 11.241, de 19 setembro de 2002, do estado de São Paulo pró́be a queima da cana-de-açúcar antes da colheita em virtude do alto impacto que a fumaça causa na saúde coletiva e no meio ambiente. Ribeiro e Ficarelli (2010) destacam que a previsão inicial era a de que até 2031 não houvesse mais queimadas. Posteriormente, um acordo entre governo do Estado e União da Indústria de Cana-de-Açúcar (Unica) reduziu o prazo para 2014 em áreas mecanizáveis e, 2017, para áreas íngremes nas quais não há possibilidade de serem mecanizáveis (Unica, 2009).

As probabilidades de ferimentos com o facão no corte de cana não queimada são maiores, pois o e a trabalhadora tem mais dificuldade de trabalhar devido a cana produzir muitas folhas, o que atrapalha a sua visão. $O$ desgaste físico também é maior. $O$ fogo afugenta os animais peçonhentos presentes na cana, agiliza a operação em locais onde o ser humano e a máquina encontrariam dificuldades para operar (Ronquim, 2010).

Por outro lado, Ribeiro e Ficarelli (2010) destacam que as queixas relativas ao estado de saúde destes homens e mulheres tendem a concentrar-se em relatos sobre dores nas costas, tosse, fadiga muscular, ardor nos olhos. A ardência nos olhos, a tosse e a falta de ar são sintomas que têm maior intensidade na época das queimadas.

Uma vez quase nos queimou no meio da cana. Nós estávamos cortando cana e punham fogo na outra cana, do lado nosso. Menina, quase morremos naquele dia. Queimou mochila das pessoas, queimou a comida, as marmitas de comida que estavam lá. Nós quase morremos sufocadas com aquela fumaça e aquele fogo que subia. Era uma vareta que subia lá em cima e ia. Naquele dia, nós passamos sufoco (Marta, 43 anos).

O relato da trabalhadora Marta evidencia a gravidade da situação relacionada às queimadas da cana-de-açúcar. Há muitos acidentes na lavoura relacionados ao incêndio dos talhões de cana. Mesmo havendo uma diminuição da queimada na lavoura, essa prática ainda é persistente. Para os trabalhadores, a queima facilita o corte manual, porém acarreta riscos de acidentes graves envolvendo os rurais. Além da gravidade desses acidentes, os homens e as mulheres que trabalham na lavoura guardam na memória os momentos de pânico e medo vivenciados no campo, como revela a trabalhadora: 
Aí eu fiquei traumatizada por um bom tempo, então, eu tenho muito medo de fogo hoje. Agora parei um pouco, mas, nossa, eu não podia ver fogo na minha frente (Ana, 59 anos).

A utilização de agrotóxicos na lavoura também incide na saúde destes trabalhadores e trabalhadoras. O Brasil, que possui uma posição de destaque em produção agrícola em escala global, é um dos países que mais utiliza agrotóxicos (Ferreira, 2015). Segundo esta mesma autora, o modelo agrícola adotado no país está fortemente vinculado ao uso de agrotóxico, considerandose também que a agricultura local está centrada em um modelo de desenvolvimento voltado a ganhos de produtividade.

O Ministério da Agricultura publicou no mês de maio de 2020 a liberação de mais 22 agrotóxicos para uso dos agricultores e, no mês de abril do mesmo ano o governo já havia autorizado outros 16 pesticidas para que a indústria consiga formular novos produtos. Dessa forma, já são 150 novas autorizações para o uso de agrotóxicos no país (Tooge, 2020).

O Ato $n^{\circ} 31$, de 4 de maio de 2020, do Departamento de Sanidade Vegetal e Insumos Agrícolas da Secretaria de Defesa Agropecuária, traz o registro de 22 defensivos agrícolas formulados para uso de agricultores (Ministério da Agricultura, 2020).

No ano anterior, em 2019, o Brasil já havia conquistado o recorde histórico de aprovações de agrotóxicos, com 475 novos produtos sendo liberados (Grigori, 2020). De acordo com o Ministério da Agricultura (2019), a produção de produtos biológicos para controle de pragas e doenças agrícolas cresceu mais de 70\% no último ano no Brasil, movimentando R $\$ 464,5$ milhões, valor bem superior ao de 2017, R \$262,4 milhões. O resultado brasileiro é considerado o mais expressivo da história do setor, superando o percentual apresentado pelo mercado internacional.

Segundo a Agência Nacional de Vigilância Sanitária (Anvisa), a exposição a agrotóxicos pode provocar uma variedade de doenças que dependem dos produtos usados, do seu tempo de uso e da quantidade que penetrou no corpo (Anvisa, 2011).

Quando acaba a safra, eu trabalho. A gente vai trabalhar com a planta, aí trabalha com produto químico. Nós vamos pondo um produto químico pra eles poderem cobrir a cana. Espalha um produto químico, o veneno. Tem cheiro forte, você põe luva, você põe máscara, mas tem o cheiro muito forte, tem o cheiro muito enjoado. Foi isso que me intoxicou uma vez (José, 35 anos).

De acordo com Levigard e Rozemberg (2004), as intoxicações por agrotóxicos são manifestadas pela diminuição das defesas imunológicas, anemia, impotência sexual masculina, incidência de cefaleia, insônia, alterações da pressão arterial, alterações do humor, depressão (distimias) e distúrbios do comportamento (surtos psicóticos), tal como sugere um dos entrevistados:

Eu chegava do trabalho, eu só tirava a roupa e deitava em cima da cama, tremia, tremia e só chorava. Me levaram lá no psiquiatra, aí passou pelo médico, ele disse: "ele está em depressão", aí passou o medicamento, aí me afastou. Aí tomava remédio, sentia dor de cabeça e não passava. Sempre passava, duas vezes na semana [terapia] (José, 35 anos).

Bedor et al. (2009) também identificaram em seus estudos alguns sintomas relacionados ao uso de agrotóxicos como dor de cabeça, irritação na pele e tontura. Castro e Confalonieri (2005) destacaram que o maior número de ocorrências de intoxicações compreende os seguintes sintomas: tonteira, dor de cabeça, dor no corpo, visão turva, dor de coluna, dor de estômago, queimação, falta de ar, vômitos, dor nas juntas, infecção nos rins, urticária, tremores, cansaço, pressão alta e problemas de fígado. 
Entre os e as entrevistadas nesta pesquisa, pôde-se também observar a incidência dos acidentes de trabalho classificados como típicos, envolvendo ferimentos com cortes provocados pelo facão; quedas no canavial, devido aos buracos no solo; quedas das máquinas agrícolas, quando o e a trabalhadora desce da máquina, e intoxicação provocada pelo manuseio de produtos químicos.

Eu estava lá cortando a cana, estava limpando a cana e bateu o facão, só que eu estava de luva, só que cortou a luva com o dedo e tudo. Eu operei, fiz cirurgia, fiquei cinco dias no hospital. Era cana na palha, é a mais difícil. Eras umas 15h, estava acabando de cortar já (Paula, 43 anos).

Ah, minha máquina tinha quebrado e ia desengatar e estava já escuro. E eu fui descer da máquina com as luzes todas apagadas e essa alça [da mochila] caiu do lado esquerdo e eu fui tentar segurar. Caí de uns oito degraus lá de cima e eu quebrei o braço tipo de um V assim (Carolina, 23 anos).

Uma intoxicação. Eu estava trabalhando no serviço e eu comecei sentir vontade de vômito [no plantio]. Aí no outro dia fui de novo, e volta e tudo o que eu via na minha frente, vinha o cheiro do veneno (José, 35 anos).

Foi um corte, um facão cortou meu pé. A cana veio com o vento e derrubou assim o facão, escorregou na frente e pegou o joelho. Ah, eu estava cansado sim, já era de tardezinha, no horário de encerrar o dia. Por causa do vento, né? Veio aquele vento assim (Pedro, 42 anos).

O ferimento cortocontuso é considerado frequente entre os e as trabalhadoras. Segundo Nunes et al. (2016), além dos cortes superficiais há ocorrências de cortes mais profundos, que podem acarretar lesões que envolvem a perda de membros ou incapacitações físicas.

Estudos de Fehlberg, Santos e Tomasi (2001) também identificaram os tipos de acidentes que acometem os e as trabalhadoras rurais. A principal lesão provocada foi o corte, seguida de contusões e queimaduras por animais peçonhentos. Entre as partes do corpo atingidas, tiveram destaque as mãos, os pés e as pernas. Todos os acidentes causados por ferramentas manuais tiveram como lesão o corte e isto também ocorreu na maioria dos acidentes causados por máquinas e implementos.

De acordo com Gonzaga e Lima (2016), o arsenal de equipamentos de proteção individual (EPI) utilizado pelos trabalhadores e trabalhadoras não tem atendido às expectativas de segurança, principalmente, no que diz respeito às luvas de proteção. Muitos são lesionados mesmo com o uso das luvas.

Os acidentes não ocorrem apenas entre as trabalhadoras e os trabalhadores manuais, mas também entre aqueles e aquelas que operam as máquinas agrícolas. Rodrigues (2014) afirma que as máquinas colhedoras de cana têm relevância nos acidentes com potencial de gerar ocorrências fatais ou deixar sequelas nas vítimas, como amputações ou mutilações.

De acordo com Nunes et al. (2016), as empresas fazem palestras e demonstrações sobre o uso dos equipamentos, porém enfatizam a responsabilidade do trabalhador no uso e na prevenção dos acidentes. Isso oferece aos empregadores e encarregados a possibilidade de abster-se da responsabilidade, pois os regulamentos de segurança foram adotados, mas o uso inadequado dos equipamentos, ou a ausência deles, passa a ser de responsabilidade de cada indivíduo. Deve-se, no entanto, considerar que a dinâmica imposta no processo produtivo, puxada pelas metas, estimuladora da competição entre trabalhadores e, não raro, remunerada por produto encontra-se na base dos processos desencadeadores de acidentes e adoecimentos.

Franco-Benatti (2011) ressalta que a utilização dos equipamentos de proteção não elimina os riscos presentes no ambiente de trabalho e, mesmo as empresas fornecendo esses equipamentos, as condições de trabalho ainda continuam inadequadas, interferindo na saúde do e da trabalhadora. 
O processo de mecanização da produção trouxe para o interior das lavouras o uso de tecnologia altamente avançada. Nas feiras agrícolas são mostradas máquinas colhedeiras de cana altamente modernas e com acessórios que poderiam proporcionar melhores condições de trabalho, a exemplo do ar condicionado. Porém, na realidade do campo, esses acessórios não estão disponibilizados nas máquinas, conforme aponta Navarro (2017).

A culpabilização também se encontra presente no discurso dos trabalhadores e trabalhadoras. Segundo Silva (2008), a maioria se sente culpada pelo ocorrido. Não raro atribuem o acidente à casualidade e não às condições e situações de trabalho que estão submetidos, tal como declararam os entrevistados nesta pesquisa:

O vento, eu estava trabalhando, de repente veio aquele vento de vez, e a cana entortou assim e na hora que eu fiz o corte, o facão pegou e escorregou em cima da cana e deu no joelho (Pedro, 42 anos).

É porque eu estava acabando depressa, né? Se eu "tivesse" cortando mais devagar, não tinha cortado, eu acho (Paula, 43 anos).

Entre os acidentes que ocorrem no meio rural, não se pode também descartar aqueles que aconteceram durante o trajeto entre a moradia e o posto de trabalho. De acordo com Rodrigues e Silva (1986, p. 29), "o próprio fato de grande parte dos trabalhadores rurais residir na cidade, tendo que se deslocar diariamente até o seu local de trabalho, acrescenta os acidentes de transporte aos acidentes de trabalho na agricultura". Segundo um dos entrevistados, "um acidente que eu presenciei foi um tombamento de um veículo de trabalhador rural, vindo embora. Uma mulher que fraturou o pé, que foi mais sério. Graças a Deus, a gente estava em outro ônibus" (Vitor, 44 anos) ${ }^{6}$.

O trabalho com a cana-de-açúcar envolve também muitos movimentos corporais como abaixar-se, abraçar certa quantidade de cana, levantar e baixar o facão, carregar a cana cortada até determinado lugar e amontoá-la em montes para facilitar o carregamento das máquinas colhedeiras. Todo esse movimento repetitivo pode acarretar sérias sequelas físicas, como lesões por esforços repetitivos e problemas osteomusculares e osteoarticulares (Nunes et al., 2016).

Falou que minha mão, o meu nervo foi muito sofrido, é o que ele falava: "você começou a trabalhar muito nova, serviço pesado, isso judiou muito", isso que ele falava. Tendinite, desvio [na coluna, provocado pelo desgaste na lavoura]. Fiz fisioterapia, fiz bastante. Ela formigava, adormecia. O meu nervo não estava do tamanho do braço, então eu tinha que ficar com o braço assim [dobrado]. Eu não esticava, porque o nervo não dava para o tamanho do braço. Aí, depois de cinco anos que eu estava lá, eu fiz a cirurgia. Eu fiz tratamento cinco anos, da mão e da coluna. Eu sentia dor, eu quase não andava (Sara, 41 anos).

Olha, o que eu tive foi no braço direito, deu tendinite crônica no braço e no outro deu bursite e o médico falou pra mim que se eu não parasse com esse serviço aí manual, essa coisa repetitiva, eu não ia conseguir nem mexer o braço mais. Aí já começou a dar problema na coluna, aí deu desgaste na coluna (Cláudia, 44 anos).

6 A história dos trabalhadores rurais empregados na agroindústria canavieira é marcada por inúmeros acidentes de trajeto graves que resultavam, invariavelmente em mortes e muitos feridos graves. Por muito tempo, os trabalhadores eram transportados como gados em carrocerias de caminhões de forma muito precária onde dividiam espaço com enxadas, foices e facões. Atualmente, é proibido o transporte de trabalhadores em caminhões sendo o mesmo feito em ônibus. No entanto, ainda que a segurança e a comodidade nos ônibus sejam maiores e os riscos de acidentes sejam menores os trabalhadores continuam sujeitos a acidentes graves nas estradas. 
Os trabalhadores e trabalhadoras sentem dores nos membros superiores, formigamento e fraqueza em suas mãos e braços. Esses sintomas são característicos de atividades marcadas por movimentos repetitivos e, no caso das e dos canavieiros, associados ao peso de cana ao cortá-la.

Eu comecei a sentir [há] muito tempo, mas eu não dava muita liga porque eu achava que isso era normal, né? Porque você abraçava cana. Era muito peso no braço, né? Porque você abraçava a cana ali de monte, jogava no monte e falava que achava que isso era cansaço. Você abraçava e jogava a cana parecia que o braço ia junto. Sabe aquela canseira no braço, aquela dor esquisitinha, mas eu achava que era disso aí, que era da cana. À noite começou a formigar, começou a doer, aí eu fui ver que que era (Cláudia, 44 anos).

Os relatos obtidos pela pesquisa mostram o intenso ritmo de trabalho na lavoura canavieira e sua repercussão na saúde desses homens e mulheres. A movimentação do corpo durante a jornada de trabalho torna-se um componente de desgaste. Além do desgaste físico, também sofrem o desgaste psíquico em decorrência das exigências do trabalho e da pressão por produzir cada vez mais. Os corpos cansados e adoecidos do árduo trabalho são uma resposta a essa intensificação que existe no trabalho manual e mecanizado.

Nos depoimentos, os e as trabalhadoras salientaram diversas formas de adoecimento, tanto físico como psíquico atribuídos ao trabalho na lavoura canavieira. Foram destacados problemas de coluna; lesões por esforços repetitivos; câimbras durante a execução da atividade; quedas de pressão; envelhecimento da pele, provocado pelo sol; intoxicações por agrotóxicos; lesões no corpo em virtude de acidente de trabalho; cansaço físico; estresse; e alterações no organismo devido ao trabalho no turno da noite.

\section{Vidas marcadas pelo trabalho}

Além dos danos visíveis no corpo, o trabalho no canavial deixa marcas nem sempre visíveis: o trabalho nos canaviais marca a vida. Trabalho duro, que fatiga, adoece e faz envelhecer precocemente. Os efeitos de um acidente na vida de um ou uma trabalhadora são catastróficos, pois a modificam inteiramente. Impossibilitam de realizar não só o trabalho, mas também outras atividades do dia a dia. Além da dor física que os acidentes provocam, estabelece-se a dor psíquica.

Os trabalhadores e as trabalhadoras, ao se acidentarem, percorrem um longo e desgastante caminho, pois, além de se manterem afastados do trabalho, vão ao médico com frequência, buscando tratamentos para sua reabilitação. "Esses fatos, somados à incapacidade de realizar o seu trabalho, acabam desgastando psicologicamente o trabalhador que, muitas vezes, entra em depressão, com estados de ansiedade extrema, nervosismo e fadiga" (Franco-Benatti, 2011, p. 193).

Ceccato et al. (2014) analisaram a frequência de afastamentos por doenças ocupacionais de trabalhadores em uma safra da cana-de-açúcar e destacaram que na entressafra, fase do plantio da cana crua, a frequência de atestados foi maior entre as doenças do sistema conjuntivo, seguidas das doenças do aparelho respiratório. No meio da safra, houve maior número de atestados de doenças osteomuscular e do tecido conjuntivo; em segundo lugar ficaram as doenças do aparelho respiratório e, em terceiro lugar, as doenças do sistema nervoso. No fim da safra, a frequência no número de atestados foi maior nas doenças do sistema osteomuscular e do tecido conjuntivo e, em segundo lugar, as doenças do aparelho respiratório.

Verçoza (2018), em estudos com canavieiros, apurou a quantidade de quilômetros caminhados, as calorias gastas ao longo da jornada, assim como a carga cardiovascular dos trabalhadores safristas. Em seu estado agudo, as fortes câimbras, resultantes da intensidade do trabalho executado, associadas 
às demais condições e situações de trabalho já descritas neste artigo, levam à completa imobilidade do corpo desses trabalhadores e trabalhadoras. É desta condição, capaz de fazer que os braços se retraiam junto ao corpo também imobilizado, que surge a expressão homem-canguru, utilizada pelos e pelas cortadoras, tal como destaca o autor.

Apesar disso, aquele ou aquela que adoece na lavoura canavieira demora em procurar um médico ou um tratamento. $\mathrm{O}$ controle da organização do trabalho sobre o trabalhador faz com que este não possa perder o dia de trabalho, já que depende da quantidade de cana cortada para receber alguns benefícios que a usina fornece:

Trabalhei um mês com dor, tomando remédio pra tirar a dor, tomava injeção. $O$ fiscal sabia, mas não gostava que perdia dia não, porque lá, eles não gostam que ficam mandando atestado, que a pessoa perde dia. Eu nunca cheguei e falei [que tinha dor], eu tinha medo dele pegar e xingar (Vitória, 39 anos).

Os acidentes de trabalho repercutem de várias formas na vida do e da trabalhadora. Além de alijá-los de sua fonte de sustento, interferem nas atividades da vida cotidiana. No caso das mulheres, percebe-se que a situação se agrava ainda mais devido às tarefas domésticas e aos cuidados com os filhos. As mulheres sentem dificuldades até mesmo para realizar as tarefas mais simples do dia a dia, como os cuidados básicos de higiene e o escovar dos cabelos:

Interferiu muito. Eu via o serviço pra fazer e eu sabia, se eu fizesse, à noite eu não dormia, mas mesmo assim eu tinha que fazer, porque eu não podia deixar, porque as meninas minhas eram tudo pequenas. Tudo era eu e eu. E eu fazia, lavava minha roupa, não aguentava torcer porque o braço não dava. Aí eu tinha que lavar e amontoar tudo pra deixar a água escorrer bem pra depois eu colocar no varal, porque eu não aguentava torcer de jeito nenhum. Eu falava para o médico: "doutor, nem pentear o cabelo eu não consigo". Nada, até hoje, eu não tenho força na mão. O cabelo mesmo conforme eu erguia assim, nossa gente que dor que dava no braço. Eu falava: "parece que esse meu braço vai cair", de tanto que doía (Cláudia, 44 anos).

O sofrimento que esses homens e mulheres passam ao se acidentar tende a ser agravado pelo sentimento de insegurança, de medo de perder o emprego. Lima, Rossini e Reimão (2010) destacam que o desemprego ocasionado pela entressafra pode influenciar no surgimento de sintomas de ansiedade e de depressão e causar prejuízos na qualidade de vida e alterações no padrão do sono dos trabalhadores rurais.

Por outro lado, a volta ao trabalho após o afastamento envolve expectativas e sensações de insegurança. $\mathrm{O}$ trabalhador sente o ambiente de trabalho estranho, pois o grupo se modifica ao longo dos meses e novos canavieiros vão chegando para o trabalho na lavoura:

É ruim, depois que eu voltei parece que a turma modifica tudo, parece que não são as mesmas pessoas. Não é que muda, parece que está tudo estranho com a gente, por causa que a gente estava afastada, aí até que vai acostumando de novo (Vitória, 39 anos).

A invisibilidade do sofrimento e da dor reflete no tratamento que ele ou ela recebem ao retornar ao trabalho. Seligmann-Silva (1994) afirma que trabalhadores que sofreram acidentes acabam sofrendo discriminação. Passam por dificuldades para o retorno ao trabalho e não apenas devido às limitações do corpo para a execução de sua atividade laboral, mas, sobretudo, aos obstáculos que enfrentam durante a trajetória percorrida para estabelecer o nexo entre o seu adoecimento e o seu trabalho: 
Fiquei quatro meses de licença. Pelo INSS recebi só três meses. Aí trabalhei quase um mês, eu peguei e voltei, aí foi onde que ele me deu uma carta como serviço leve dentro da usina. Aí depois que eu levei essa carta, que eu entreguei na mão do turmeiro, eu ainda trabalhei umas duas semanas cortando cana, picando, tudo normal, aí depois que o encarregado foi lá e mandou ele colocar eu pra passar veneno no facão, só que tem muita gente que fala pra mim que eu sou muito boba, porque o serviço que eu estou fazendo lá, bem dizer é três, porque é tomar conta do ônibus, passar o veneno, e passar água como bombeira. Pega 15 litros de água todo dia, aí eles falam que isso aí não é serviço leve, porque passar água não é serviço leve, tem que se esforçar do mesmo jeito, aí eu falei, que tenho que fazer, porque é obrigação (Vitória, 39 anos).

Os trabalhadores e trabalhadoras também ficam com medo de sofrer, novamente, um acidente de trabalho. A volta ao ambiente de trabalho traz na memória momentos de dor e sofrimento vivenciados durante o exercício da atividade.

A pessoa fica um pouco assustada uns dias, depois. Aí agora, dá medo, né? É a gente fica assim, um pouco abatido, ninguém quer sofrer acidente, mas infelizmente acontece, né? Não é coisa boa não, não é bom. Isso ficou marcante, fica meio [chocado], né? (Pedro, 42 anos).

Seligmann-Silva (2011, p. 310) destaca que a reação aguda ao estresse é o distúrbio psíquico mais comum entre aqueles que podem aparecer após o acidente: "Num prazo maior, desenvolvem-se outros quadros de transtorno mental ao longo dos desdobramentos das perdas e constrangimentos resultantes do acidente. Pois devemos considerar que os acidentes - conforme sua gravidade costumam trazer sequelas físicas, funcionais e sociais".

O sofrimento também marca a trajetória que ele ou ela deverá percorrer para comprovar sua incapacidade para continuar desempenhando suas atividades, estabelecer o nexo entre o acidente e sua atividade laboral e, consequentemente, obter acompanhamento e tratamento adequados às suas condições de saúde. De acordo com Cohn et al. (1985, p. 52) “ a brutalidade da qual o acidente é revestido não se resume apenas ao acidente em si e as circunstâncias em que ele ocorre, mas se estende ao longo processo de tratamento e a trajetória institucional que o acidentado é obrigado a percorrer".

E fui ao INSS e os médicos me recusaram lá, porque eles falaram que essa mão aqui, se fosse essa outra mão aqui, tudo bem, mas como era essa aqui [a esquerda] dava para eu trabalhar. É que eu podia trabalhar, o moço lá no INSS, ele nem olha na cara da gente: "não posso fazer nada, pega uma carta lá com seu médico por causa do serviço, porque a gente não pode fazer nada". Eu consegui os três meses que eu fiquei afastada, depois eu não consegui mais não, aí eu tive que trabalhar (Paula, 43 anos).

Essa longa trajetória percorrida pelo acidentado acarreta desgaste e insatisfação frente ao não reconhecimento por parte do empregador e dos órgãos públicos acerca do adoecimento e do acidente. A insatisfação tende a desencadear sentimentos como a vergonha de se sentir incapaz para realizar qualquer outra atividade, acentuada pelo julgamento social.

Sentimento de inutilidade, não só nesses oito meses, como nesse um ano agora. É duro assim, olha pra mim, o que eu tenho? Então, as pessoas veem você passando de carro ali, não sabe o que que aconteceu ali, e fala "o cara ali é vagabundo, ele não trabalha". A mulher falou aqui pra mim na esquina: "vai trabalhar pra sustentar sua família". Sabe, não sabe o que você tem. Na época da coluna, eu andava [curvado], já era uma época que eu não aguentava andar. Era chato, e você saia na rua, os amigos falavam: "oh vai trabalhar você é forte", mas não sabe o que você estava passando (Fernando, 35 anos). 


\section{Considerações finais}

Os trabalhadores e trabalhadoras tendem a sentir prazer na atividade que desempenham quando favorecidos por uma relação social positiva no ambiente de trabalho. Essa possibilidade tende cada vez mais a se constituir como horizonte distante - para muitos, inatingível -, na medida em que avançam as diferentes e articuladas formas de precarização do trabalho. No caso da lida no canavial, essa realidade é velha conhecida, tal como indicam diversas pesquisas.

Vínculos contratuais instáveis e temporários; baixa remuneração; pouco acesso a direitos; condições de trabalho degradantes; dinâmica de trabalho ancorada em metas crescentes, sob intenso controle, voltadas à ampliação da intensificação do ritmo e da produtividade; trabalho exaustivo, que mói o corpo, desvalorizado socialmente dentro e fora do ambiente de trabalho; entre outros aspectos, são dimensões presentes na lida cotidiana desses homens e mulheres dos canaviais. O sentimento de desvalorização e não reconhecimento, destacado por uma das entrevistadas, está na base de uma das formas de sofrimento psíquico vivenciado pelos canavieiros.

Esse contexto torna-se ainda mais dramático pela ocorrência do acidente típico ou adoecimento com nexo laboral, seja este incapacitante temporariamente ou de forma permanente. $\mathrm{O}$ trabalho, duro e sofrido, guarda o sentido da sobrevivência. Quando ocorre, rouba desses homens e mulheres o pouco que lhes resta de reconhecimento social: a capacidade de prover seu sustento e de seus familiares, a capacidade de sentirem-se úteis frente a família e a sociedade.

Não me senti valorizada não. Porque é assim: eles precisaram da gente quando estava bem, trabalhando. A partir da hora da doença, te mandam pra rua, que nem um cachorro pra rua. A gente não serve mais. E não era pra ser assim (Sara, 41 anos).

Não é apenas a vida do indivíduo no trabalho que está afetada e prejudicada. Tal como afirma Antunes (2000, p. 175, grifo do autor): "uma vida desprovida de sentido no trabalho é incompatível com uma vida cheia de sentido fora do trabalho".

Essa percepção, de um trabalho esvaziado de sentido, faz com que parte desses homens e mulheres alimentem a esperança de que seus filhos construam outras travessias, que enganem um destino que parece persegui-los, que busquem um trabalho e um futuro distantes da atividade na lavoura. Justo desejo é esse que move esses homens e mulheres do canavial.

Eu penso é nos meus filhos, o futuro. Está tudo ocorrendo bem, a gente estando empregado, com saúde. Para meus filhos eu falo: "procurar estudar" para eles terem um futuro diferente. É a minha vontade, mas a gente não sabe. Se for preciso amanhã ou depois sair desse emprego, e aí a gente encara qualquer coisa. Não, eu acho que cortar cana eu não aguento mais, mas se precisar a gente vai, com laranja (Vitor, 44 anos).

Entretanto, é em direção a estes espaços de trabalho que rumam, a cada safra, centenas de milhares de trabalhadores. Destituídos de outras possibilidades de sustento, o fluxo em direção aos canaviais renova-se a cada temporada de colheita.

Ao fim da caminhada deparam-se com uma lavoura que tem passado por profundas modificações organizacionais e tecnológicas nas últimas décadas. Mas essas transformações, entretanto, não retiraram do cotidiano do trabalho suas características precárias e favoráveis às ocorrências de acidentes e doenças com nexo laboral.

As antigas condições e situações de trabalho persistem. Renovam-se em meio à chamada modernização da atividade agroindustrial da cana. Os dados da pesquisa demonstraram que as transformações que ocorreram, nas últimas décadas, somadas à intensificação do trabalho e às 
persistentes condições de precariedade que marcam a vida dentro e fora do ambiente laboral dialogam claramente com ocorrências de acidentes e adoecimentos relacionados ao trabalho. Os círculos viciosos se completam - persistem.

Os novos processos de reorganização do trabalho e seus efeitos deletérios na vida dos trabalhadores e trabalhadoras são resultados da atual fase de desenvolvimento do capitalismo e do avanço de medidas neoliberais. Esse avanço atinge, de formas mais singulares, os países que compõem a periferia do sistema, apresentando, de forma mais ampliada, a questão da exploração e precariedade no trabalho.

É na busca por criar mecanismos que interrompam estes processos que essa pesquisa se insere. Ao desvelar aspectos da dinâmica produtiva nos canaviais e a persistência do desgaste e adoecimento do trabalho, busca contribuir com o desenvolvimento de ações voltadas a estratégias preventivas, desencadeadas tanto pelos serviços de atenção à saúde do trabalhador, como pelas entidades representativas desses trabalhadores. Pretende ainda, de forma decorrente, subsidiar a elaboração de políticas sociais voltadas à promoção, proteção e recuperação da saúde desses homens e mulheres cujas vidas foram e continuam sendo marcadas pelo trabalho duro, desvalorizado, que faz sofrer e adoecer.

\section{Referências}

Agência Nacional de Vigilância Sanitária. (2011). Cartilha sobre agrotóxicos (Série Trilhas do Campo). Brasília, DF: Anvisa. Alessi, N. P. \& Navarro, V. L. (1997). Saúde e trabalho rural: o caso dos trabalhadores da cultura canavieira na Região de Ribeirão Preto, São Paulo, Brasil. Cadernos de Saúde Pública, 13(Supl.2), 111-121.

Alves, F. (2007). Migração de trabalhadores rurais do Maranhão e Piauí para o corte de cana em São Paulo: será esse fenômeno casual ou recorrente da estratégia empresarial do Complexo Agroindustrial Canavieiro? In J. R. Novaes \& F. Alves (Orgs.), Migrantes: trabalho e trabalhadores no complexo agroindustrial canavieiro (os heróis do agronegócio brasileiro) (pp. 21-54). São Carlos, SP: EdUFSCar.

Alves, F. (2008). Processo de trabalho e danos à saúde dos cortadores de cana. InterfacEHS - Revista de Gestão Integrada em Saúde do Trabalhador e Meio Ambiente, 3(2), 1-26.

Antunes, R. (2000). Os sentidos do trabalho: ensaio sobre a afirmação e a negação do trabalho. São Paulo: Boitempo.

Araújo, P. F. C., Schuh, G. E., Barros, A. L. M., Shirota, R. \& Nicolella, A. C. (2003). O crescimento da agricultura paulista e as instituições de ensino, pesquisa e extensão numa perspectiva de longo prazo: relatório final do projeto contribuição da Fapesp à agricultura do estado de São Paulo. São Paulo: Fapesp.

Bedor, C. N. G., Ramos, L. O., Ferreira, P. J., Rêgo, M. A. V., Pavão, A. C. \& Augusto, L. G. S. (2009). Vulnerabilidades e situações de riscos relacionados ao uso de agrotóxicos na fruticultura irrigada. Revista Brasileira de Epidemiologia, $12(1)$, 39-49.

Bezerra, L. \& Tavares, M. A. (2016). Produtividade e miséria: o trabalho assalariado nos canaviais da Paraíba. SER Social, Brasília, 18(39), 562-583.

Brasil. Ministério da Agricultura, Pecuária e Abastecimento. Secretaria da Defesa Agropecuária. Ato n 31, de 4 de maio de 2020. (2020). Brasília, DF: Diário Oficial da União.

Cabral, L. A. A., Soler, Z. A. S. G. \& Lopes, J. C. (2014). “Acidente de dupla espécie”: uma terceira espécie de acidente do trabalho e sua importância para a vigilância em saúde do trabalhador. Ciência E̊ Saúde Coletiva, 19(12), 4699-4708.

Castro, J. S. M. \& Confalonieri, U. (2005). Uso de agrotóxicos no Município de Cachoeiras de Macacu (RJ). Ciência Eే Saúde Coletiva, 10(2), 473-482.

Ceccato, A. D. F., Carvalho Junior, L. C. S., Cuissi, R. C., Monteshi, M., Oliveira, N. G., Padovani, C. R., Ramos, E. M. C. \& Ramos, D. (2014). Absenteísmo por doença ocupacional de trabalhadores rurais no setor canavieiro. Cadernos de Saúde Pública, Rio de Janeiro, 30(10), 2169-2176.

Cohn, A., Hirano, S., Karsch, U. S. \& Sato, A. K. (1985). Acidentes do trabalho: uma forma de violência. São Paulo: Brasiliense. 
Dal Rosso, S., Barbosa, M. L. \& Fernandes Filho, H. P. (2001). Intensidade do trabalho e acidentes. In J. F. da Silva., R. B. de Lima \& S. Dal Rosso (Orgs.). Trabalho e violência no Brasil (pp. 87-104). Goiânia: Ed. UFG; Brasília: MNDH.

Dejours, C. (1992). A loucura do trabalho: estudo de psicopatologia do trabalho. São Paulo: Oboré.

Dejours, C. (2012). Trabalho Vivo: trabalho e emancipação (Tomo II). Brasília, DF: Paralelo 15.

Fehlberg, M. F., Santos, I. S. \& Tomasi, E. (2001). Acidentes de trabalho na zona rural de Pelotas, Rio Grande do Sul, Brasil: um estudo transversal de base populacional. Cadernos de Saúde Pública, Rio de Janeiro, 17(6), 1375-1381.

Ferreira, M. L. P. C. (2015). A pulverização aérea de agrotóxicos no Brasil: cenário atual e desafios. Revista Direito Sanitário, São Paulo, 15(3), 18-45.

Ferreira, L. L., Gonzaga, M. C., Donatelli, S. \& Bussacos, M. A. (2008). Análise coletiva do trabalho dos cortadores de cana da região de Araraquara - São Paulo (2a ed.). São Paulo: Fundacentro.

Franco-Benatti, D. M. (2011). Acidentes e doenças relacionadas ao trabalho na indústria de calçados de Franca-SP. Dissertação de Mestrado, Faculdade de Medicina de Ribeirão Preto, Universidade de São Paulo, Ribeirão Preto, SP.

Grigori, P. (2020). 118 agrotóxicos são aprovados durante a pandemia, liberação é "serviço essencial”. Agência Pública/ Repórter Brasil. Recuperado de https://reporterbrasil.org.br/2020/05/96-agrotoxicos-sao-aprovados-durante-apandemia-liberacao-e-servico-essencial/

Gonzaga, M. C. \& Lima, C. Q. B. (2016). Dificuldades e limitações das luvas de proteção usadas no corte manual da cana. Laboreal, pesquisa empírica, 12(1), 77-87.

Instituto Brasileiro de Geografia e Estatística. (2018). Pesquisa nacional por amostra de domicílios contínua. Divulgação Especial. Medidas de subutilização da força de trabalho no Brasil. 2º trimestre de 2018. Recuperado de https:// agenciadenoticias.ibge.gov.br/agencia-detalhe-de midia.html?view $=$ mediaibge\&catid $=2103 \& i d=2266$

Instituto Nacional de Seguro Social. (2018). MDS: Pente-fino do INSS inicia nova etapa e convoca 522 mil beneficiários. Recuperado de https:/www.inss.gov.br/mds-pente-fino-do-inss-inicia-nova-etapa-e-convoca-522-mil-beneficiarios/

Lei $n^{\circ}$ 11.241, de 19 de setembro de 2002. (2002). Dispõe sobre a eliminação gradativa da queima da palha da cana-deaçúcar e dá providências correlatas. São Paulo: Diário Oficial do Estado.

Levigard, Y. E. \& Rozemberg, B. (2004). A interpretação dos profissionais de saúde acercadas queixas de "nervos" no meio rural: uma aproximação ao problema das intoxicações por agrotóxico. Cadernos de Saúde Pública, 20(6), 1515-1524.

Lima, J., Rossini, S. \& Reimão, R. (2010). Sleep disorders and quality of life of harvesters rural labourers. Arquivos de Neuro-Psiquiatria, 68(3), 372-376.

Matos, P. F., Fratari, M. F. \& Carvalho, R. G. (2018). Fim do corte manual da cana-de-açúcar na microrregião de Ituiutaba (MG) e os impactos para os trabalhadores. Caminhos de Geografia, 19(65), 194-203.

Ministério da Agricultura. (2019). Mercado de biodefensivo cresce mais de 70\% no Brasil em um ano. Recuperado de https:// www.gov.br/agricultura/pt-br/assuntos/noticias/feffmercado-de-biodefensivos-cresce-em-mais-de-50-no-brasil

Ministério da Agricultura. (2020). Mapa registra 22 defensivos agrícolas genéricos, incluindo produtos biológicos. Recuperado de https://www.gov.br/agricultura/pt-br/assuntos/noticias/mapa-registra-22-defensivos-agricolas-genericos-comprodutos-biologicos

Ministério do Desenvolvimento Social. (2016). INSS define regras para revisão dos benefícios por incapacidade. Recuperado de http:// mds.gov.br/area-de-imprensa/noticias/2016/agosto/inss-define-regras-para-revisao-dos-beneficios-por-incapacidade

Ministério da Fazenda. (2016). Anuário Estatístico de Acidentes do Trabalho. Brasília, DF: MF.

Ministério Público do Trabalho. (2018). Brasil é quarto lugar no ranking mundial de acidentes de trabalho. Recuperado de https://mpt.mp.br/pgt/noticias/brasil-e-quarto-lugar-no-ranking-mundial-de-acidentes-de-trabalho

Motta, C. (2017). Revisão de benefícios ou caça aos doentes? (Sindicato dos Bancários e Financiários de São Paulo, Osasco e Região, Entrevistador). Recuperado de http://spbancarios.com.br/08/2017/revisao-de-beneficios-ou-caca-aos-doentes

Navarro, V. L. (2017). Reforma trabalhista: "É muito atraso, é muito retrocesso". Entrevista com Vera Lucia Navarro (EPSJV/Fiocruz, Entrevistador). Recuperado de https://www.ihu.unisinos.br/573562-reforma-trabalhista-e-muito-atraso-e-muito-retrocesso

Novaes, J. R. P. (2007). Campeões de produtividade: dores e febres nos canaviais paulistas. Estudos Avançados, 59(21), 167-177.

Nunes, D. M. P., Silva, M. S. \& Cordeiro, R. L. M. (2016). A experiência de trabalho e dos riscos entre os trabalhadoresmigrantes nordestinos nos canaviais paulistas. Saúde e Sociedade, 25(4), 1122-1135. 
Penteado, A. C. A., Sanches, F. P. P., Castelane, R. G., Valderrama, T. V. B. P. \& Magagnini, M. A. M. (2013). Ocorrência de acidentes de trabalho com trabalhadores no corte manual da cana-de-açúcar, CuidArte Enfermagem, 7(1), 51-58.

Praun, L. (2016). Reestruturação produtiva, saúde e degradação do trabalho. Campinas, SP: Papel Social.

Ribeiro, H. \& Ficarelli, T. R. A. (2010). Queimadas nos canaviais e perspectivas dos cortadores de cana-de-açúcar em Macatuba, São Paulo. Saúde e Sociedade, 19(1), 48-63.

Rodrigues, D. A. (2014). Acidentes graves e fatais no trabalho de corte mecanizado de cana-de-açúcar: o olhar através do método mapa. Dissertação de Mestrado, Universidade Estadual Paulista Júlio de Mesquita Filho, Botucatu, SP.

Rodrigues, V. L. G. S. \& Silva, J. G. (1986). Acidentes de trabalho e modernização da agricultura brasileira. Revista Brasileira de Saúde Ocupacional, 14(56), 28-39.

Ronquim, C. C. (2010). Queimada na colheita da cana-de-açúcar: impactos ambientais, sociais e econômicos. Campinas, SP: Embrapa Monitoramento por Satélite.

Rosa, L. A. \& Navarro, V. L. (2014). Trabalho e trabalhadores dos canaviais: perfil dos cortadores de cana da região de Ribeirão Preto (SP). Cadernos de Psicologia Social do Trabalho, 17(1), 143-160.

Scopinho, R. A., Eid, F., Vian, C. E. F. \& Silva, P. R. C. (1999). Novas tecnologias e saúde do trabalhador: a mecanização do corte da cana-de-açúcar. Cadernos de Saúde Pública, 15(1), 147-161.

Seligmann-Silva, E. (1994). Desgaste mental no trabalho dominado. São Paulo: Cortez.

Seligmann-Silva, E. (2011). Trabalho e desgaste mental: o direito de ser dono de si mesmo. São Paulo: Cortez.

Silva, M. A. M. (2008). Mortes e acidentes nas profundezas do "mar de cana" e dos laranjais paulistas. Interfacehs Revista de Gestão Integrada em Saúde do Trabalho e Meio Ambiente, 3(2), 1-31.

Silveira, C. A., Robazzi, M. L. C. C., Marziale, M. H. P. \& Dalri, M. C. B. (2005). Acidentes de trabalho entre trabalhadores rurais e da agropecuária identificados através de registros hospitalares. Ciência, Cuidado e Saúde, 4(2), 120-128.

Tooge, R. (2020). Governo libera o registro de 22 agrotóxicos genéricos para uso dos agricultores. Recuperado de https:// g1.globo.com/economia/agronegocios/noticia/2020/05/12/governo-libera-o-registro-de-44-agrotoxicosgenericos-e-2-biologicos-ineditos-para-uso-dos-agricultores.ghtml

União da Indústria de Cana-de-Açúcar. (2009). Protocolo Agroambiental do Setor Sucroalcooleiro. São Paulo: Unica.

União da Indústria de Cana-de-Açúcar. (2019). Observatório da cana. Recuperado de https://observatoriodacana.com.br/

Veiga, R. K., Gontijo, L. A., Masiero, F. C., Maas, L. \& Odorizzi, W. (2017). Caracterização de acidentes com tratores de rabiças no cultivo da cebola em Santa Catarina. Horticultura Brasileira, 35 (1), 124-128.

Verçoza, L, V. (2018). Os homens-cangurus dos canaviais alagoanos: um estudo sobre trabalho e saúde. Maceió: Edufal.

Vilela, R. A. G., Laat, E. F., Luz, V. G., Silva, A. J. N. \& Takahashi, M. A. C. (2015). Pressão por produção e produção de risco: A “maratona” perigosa do corte manual da cana-de-açúcar. Revista Brasileira de Saúde Ocupacional, 40(131), 30-48.

\section{Endereços para correspondência}

dathiemello@yahoo.com.br

vnavarro@usp.br

lupraun@uol.com.br

Recebido em: 31/10/2019

Revisado em: 22/06/2020

Aprovado em: 05/08/2020 